Gut, 1975, 16, 181-185

\title{
Red cell abnormalities associated with sulphasalazine maintenance therapy for ulcerative colitis
}

\author{
R. E. POUNDER, E. R. CRAVEN, JOAN S. HENTHORN, AND \\ J. MELINDA BANNATYNE
} From the MRC Gastroenterology Unit and Department of Haematology, Central Middlesex Hospital,
London

SUMMARY Of 50 patients receiving a mean dose of $2.5 \mathrm{~g}$ sulphasalazine/day as maintenance therapy for ulcerative colitis, 35 were found to have one or more drug-induced red cell abnormalities, which were not found in 50 normal controls or in 10 colitics not receiving sulphasalazine. Twenty-three of the treated patients had contracted red cells, an abnormality that is thought to result in mild haemolysis. Red cell contraction was related to the dose of sulphasalazine $(P<0.01)$, the serum total sulphapyridine level ( $P<0.001$ ), and acetylator status. Eleven of the treated patients had a macrocytosis, 21 had elevated levels of methaemoglobin, and one had Heinz bodies. A dose of $1.5 \mathrm{~g}$ sulphasalazine/day was not associated with red cell contraction, and is suggested as a safer maintenance dose for the asymptomatic colitic.

The use of sulphasalazine (Salazopyrin, Pharmacia) in ulcerative colitis was first described by Svartz in 1942. It was established as the basis of maintenance therapy for this disease by Misiewicz, Lennard-Jones, Connell, Baron, and Jones (1965). This work was confirmed by Dissanayake and Truelove (1973) who concluded that sulphasalazine should be administered indefinitely to colitics in remission unless contraindicated by side effects.

Sulphasalazine consists of sulphapyridine linked to 5-amino salicylic acid. It is thought to pass intact through the small intestine to the large intestine, where the azo link is broken by colonic bacteria and the two constituents are absorbed by the colon (Schröder and Campbell, 1972). The adverse reactions of sulphasalazine have been related to the serum level of the sulphonamide moiety, sulphapyridine (Das, Eastwood, McManus, and Sircus, 1973a).

Sulphonamide-induced red cell damage was first described by Harvey and Janeway in 1937. It is now recognized by the presence of one or more of the following abnormalities: a characteristic irregular contraction of some of the red cells (fig 1), elevated levels of methaemoglobin, or Heinz bodies in some of the red cells (Dacie, 1967). Moeschlin (1940) described red cell damage associated with the use of

Received for publication 21 November 1974. sulphapyridine, but Spriggs, Smith, Griffith, and Truelove (1958) first reported Heinz body anaemia occurring in four of 32 patients receiving sulphasalazine.

There have been a number of descriptions of occasional cases of red cell abnormality occurring in patients receiving sulphasalazine (Shinton and Wilson, 1960; Best, 1963; Gardner and Bargen, 1964; Misiewicz et al, 1965; Cohen, Rosenthal, and Karp, 1968; Dyer, 1972; Fishman, Baron, and Orlina, 1973). In only three series were systematic observations reported in large groups of patients: Böttiger, Engstedt, Lagercranz, and Nyberg (1963) found Heinz bodies in four of 53 such patients; Dick, Grayson, Carpenter, and Petrie (1964) described haemolysis in one of 40 patients; and Das et al (1973a) observed frank haemolysis in five of 133 patients. This low reported incidence of red cell abnormalities does not correspond with our own experience, and the present study was initiated to determine the incidence of such changes.

\section{Subjects and Methods}

SUBJECTS

Fifty outpatients receivin $\mathrm{g}$ sulphasalazine as maintenance therapy for ulcerative colitis (mean daily dose $2.5 \mathrm{~g}$, range $0.5-4.0 \mathrm{~g}) ; 10$ outpatients with ulcerative colitis, but not receiving sulphasalazine; 


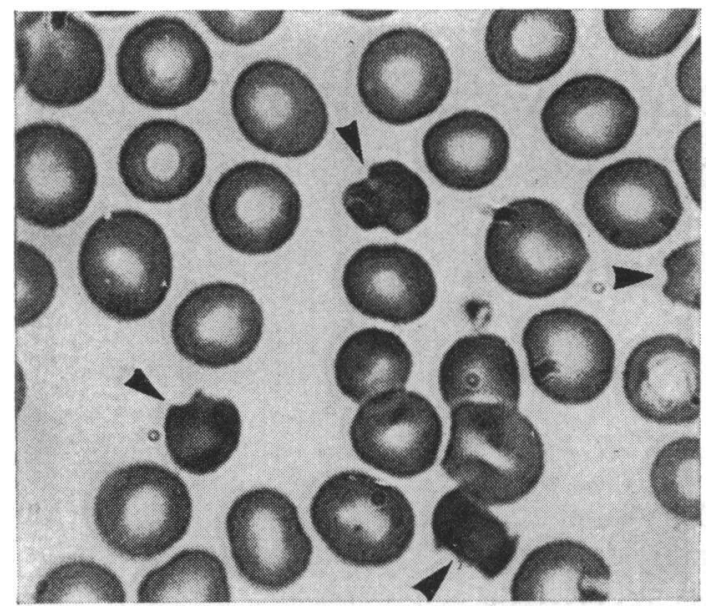

Fig 1 Contracted red cells (arrowed). Patient taking 3 g/day sulphasalazine.

and as control subjects, 50 medical or laboratory staff who stated that they were taking no drugs.

\section{METHODS}

All blood samples were taken before 10.30 a.m. during one week, equal numbers of patients and controls being examined on each day. The treated patients took no drugs on the morning of the investigation. Haematological studies were performed on the day that the blood was collected; serum was stored at $-70^{\circ} \mathrm{C}$ for biochemical studies.

Blood films were prepared at the time of venepuncture without the use of an anticoagulant, and were stained with May-Grunwald-Giemsa. Red cell morphology was assessed independently by two observers (E.R.C. and J.S.H.) who examined the films in a random sequence unaware of their origin. Each observer reported the presence or absence of abnormal contracted red cells. Some films were duplicated and included twice, and confirmed the consistency of reporting of each observer.

Haemoglobin and mean corpuscular volume (MCV) were estimated using a Coulter counter model S. Reticulocytes were stained supravitally using new methylene blue, and $0.5 \%$ methyl violet in saline was used for the Heinz body preparation. Methaemoglobin and sulphaemoglobin were estimated using methods described by Dacie and Lewis (1968) based on those of Evelyn and Malloy (1938). Glucose-6-dehydrogenase (G6PD) levels were estimated quantitatively using a Biochemica test combination kit (Boehringer Mannheim GmbH). Direct antihuman globulin tests were performed using a broad-spectrum antiserum at two dilutions.
Serum $B_{12}$ and folate levels were determined by the routine laboratory using a microbiological assay.

Serum total sulphapyridine levels (the sum of the serum levels of unconjugated sulphapyridine, acetyl sulphapyridine, sulphapyridine-o-glucuronide, and acetyl sulphapyridine-o-glucuronide) and acetyl sulphapyridine levels were estimated using the methods described by Hansson and Sandberg (1973). Liver function tests were performed in the routine laboratory.

\section{Results}

The haematological results for the patients and controls are summarized in table I. No abnormalities were observed in the white cells or platelets.

The two observers independently reported abnormal contracted red cells in 23 of the patients treated with sulphasalazine. This change was seen in neither the untreated colitics nor the normal controls. The 23 patients with contracted red cells were compared with the remaining 27 of that group and the results are summarized in table II.

Figure 2 shows the distribution of MCV estimations for the three groups investigated. In the treated group there were 11 patients with an MCV greater than $93.5 \mathrm{fl}$ (mean control group $+2 \mathrm{SD}$ ), and they are compared with the remaining 39 of that group in table II. The 11 patients all had normal liver function tests (serum bilirubin, albumin, globulin, alkaline phosphatase, and alanine transaminase) and normal serum $B_{12}$ levels, but one patient had a low

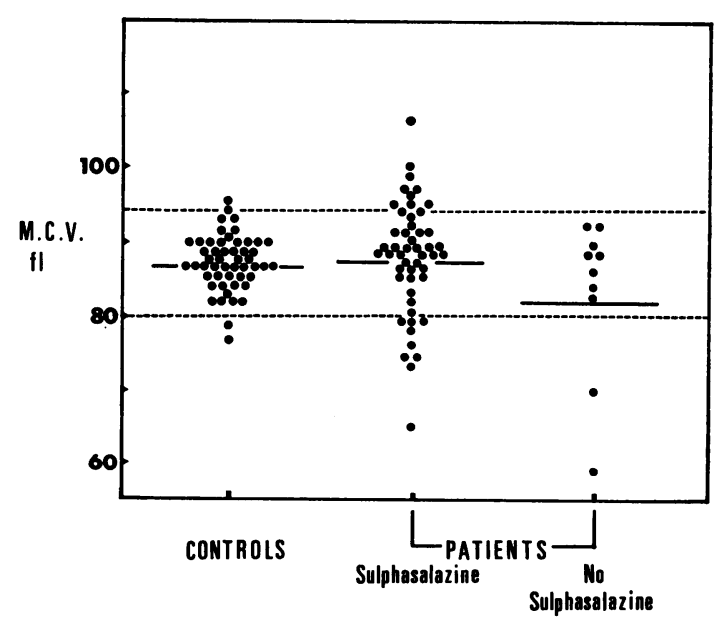

Fig 2 Mean corpuscular volume. Horizontal bars show mean of each group; broken lines $\pm 2 S D$ of mean of control group. 


\begin{tabular}{|c|c|c|c|}
\hline \multirow[t]{2}{*}{ Haematological Measurement } & \multicolumn{3}{|l|}{ Number } \\
\hline & Normal Controls & $\begin{array}{l}\text { Colitics Taking } \\
\text { Sulphasalazine }\end{array}$ & $\begin{array}{l}\text { Colitics Not Taking } \\
\text { Sulphasalazine }\end{array}$ \\
\hline $\begin{array}{l}\text { Haemoglobin (g/dl) } \\
\text { MCV (fi) }\end{array}$ & $\begin{array}{l}50 \\
14.4 \pm 0.2 \\
(12.4-16.8)^{1} \\
86.6 \pm 0.5\end{array}$ & $\begin{array}{l}50 \\
13 \cdot 5 \pm 0.2 \\
(9 \cdot 6-16 \cdot 5) \\
87 \cdot 5 \pm 1 \cdot 1 \\
(65-106\end{array}$ & $\begin{array}{l}10 \\
13 \cdot 0 \pm 0.6 \\
(9 \cdot 3-15 \cdot 2) \\
82 \cdot 7 \pm 3 \cdot 7 \\
(59.92)\end{array}$ \\
\hline Reticulocytes (\%) & $\mathrm{ND}^{2}$ & $\begin{array}{l}(0.5-100) \\
1 \cdot 5 \pm 0.1 \\
(0.4-4 \cdot 0)\end{array}$ & $\begin{array}{l}1.0 \pm 0.1 \\
(0 \cdot 4-1 \cdot 8)\end{array}$ \\
\hline Contracted red cells & $\begin{array}{l}\text { Absent } \\
50 / 50\end{array}$ & $\begin{array}{l}\text { Present } \\
23 / 50\end{array}$ & $\begin{array}{l}\text { Absent } \\
10 / 10\end{array}$ \\
\hline Methaemoglobin ( $\%$ of haemoglobin) & $\begin{array}{l}1 \cdot 1 \pm 0.4 \\
(0.5-1 \cdot 6)\end{array}$ & $\begin{array}{l}1 \cdot 4 \pm 0 \cdot 1 \\
(0 \cdot 1-2 \cdot 9)\end{array}$ & $\begin{array}{l}1.0 \pm 0.2 \\
(0.4-1 \cdot 8)\end{array}$ \\
\hline Sulphaemoglobin & ND & $\begin{array}{l}\text { Absent } \\
50 / 50\end{array}$ & ND \\
\hline Heinz bodies & ND & $\begin{array}{l}\text { Present } \\
1 / 50\end{array}$ & ND \\
\hline Glucose-6-phosphate dehydrogenase & ND & $\begin{array}{l}\text { Normal } \\
50 / 50\end{array}$ & ND \\
\hline Direct antihuman globulin test & ND & $\begin{array}{l}\text { Negative } \\
50 / 50\end{array}$ & ND \\
\hline
\end{tabular}

Table I Haematological results (mean \pm SEM)

'Range; 'ND not done

\begin{tabular}{|c|c|c|c|c|c|c|}
\hline & \multicolumn{6}{|c|}{ Nos. of Patients } \\
\hline & \multicolumn{3}{|c|}{ Contracted Red Cells } & \multicolumn{3}{|c|}{ Mean Corpuscular Volume } \\
\hline & Absent & Present & $\begin{array}{l}\text { Signifi- } \\
\text { cance }\end{array}$ & $<93.5 f^{2}$ & $>93.5 f^{3}$ & $\begin{array}{l}\text { Signifi- } \\
\text { cance }\end{array}$ \\
\hline $\begin{array}{l}\text { Haemoglobin (g/dl) } \\
\text { MCV (fi) } \\
\text { Contracted red cells } \\
\text { Methaemoglobin ( \% of haemoglobin) } \\
\text { Reticulocyte count }(\%) \\
\text { Sulphasalazine (g taken in preceding week) } \\
\text { Serum total sulphapyridine level (mg/l) } \\
\text { Sulphapyridine acetylated (\%) } \\
\text { Months of treatment with sulphasalazine } \\
\text { Serum bilirubin ( } \mu \mathrm{mol} / \mathrm{l})\end{array}$ & $\begin{array}{l}27 \\
13.7 \pm 0.3^{1} \\
85.3 \pm 1.4 \\
-\quad \\
1.3 \pm 0.1 \\
1.3 \pm 0.1 \\
15.6 \pm 1.2 \\
13.4 \pm 1.2 \\
53.0 \pm 5.8 \\
34 \pm 6 \\
9.06 \pm 0.51\end{array}$ & $\begin{array}{l}23 \\
13.2 \pm 0.2 \\
90.2 \pm 1.5 \\
- \\
1.5 \pm 0.2 \\
1.7 \pm 0.2 \\
20.7 \pm 0.9 \\
25.9 \pm 3.0 \\
35.0 \pm 4.4 \\
37 \pm 7 \\
9.24 \pm 0.68\end{array}$ & $\begin{array}{l}\text { NS } \\
<0.05^{2} \\
- \\
\text { NS } \\
<0.05^{2} \\
<0.01^{2} \\
<0.001^{2} \\
<0.02^{2} \\
\text { NS } \\
\text { NS }\end{array}$ & $\begin{array}{l}39 \\
13.4 \pm 0.2 \\
- \\
\text { Present } 15 \\
1.4 \pm 0.2 \\
1.4 \pm 0.1 \\
17.6 \pm 1.0 \\
16.5 \pm 1.5 \\
45.6 \pm 4.7 \\
36 \pm 5 \\
9.06 \pm 0.51\end{array}$ & $\begin{array}{l}11 \\
13.7 \pm 0.3 \\
- \\
\text { Present } 8 \\
1.4 \pm 0.2 \\
2.0 \pm 0.3 \\
19.5 \pm 1.0 \\
28.7 \pm 5.2 \\
41.7 \pm 6.8 \\
32 \pm 13 \\
9.41 \pm 1.03\end{array}$ & $\begin{array}{l}\text { NS } \\
<0.05^{4} \\
\text { NS } \\
<0.02^{2} \\
\text { NS } \\
<0.01^{2} \\
\text { NS } \\
\text { NS } \\
\text { NS }\end{array}$ \\
\hline
\end{tabular}

Table II Results related to presence of contracted red cells or macrocytosis in patients treated with sulphasalazine ${ }^{1}$ Mean \pm SEM; ${ }^{2}$ Student's $t$ test; ${ }^{3} \mathrm{NS}$ not significant (P > 0.05); ‘ $x^{2}$ test

serum folate level $(2 \cdot 4 \mu \mathrm{g} / 1$, normal range $2 \cdot 5-20$ $\mu \mathrm{g} / \mathrm{l})$.

Eleven patients with colitis had a microcytosis $(\mathrm{MCV}<80 \mathrm{fl})$ : two in the untreated group and nine in the treated group. Haemoglobin electrophoresis demonstrated that one of the patients had the thalassaemia trait, the remaining 10 all had bloodfilm changes characteristic of iron deficiency. One patient had a low serum folate $(2.0 \mu \mathrm{g} / \mathrm{l})$ but an MCV of $79 \mathrm{fl}$ due to iron deficiency.

Figure 3 shows the percentage of haemoglobin in the form of methaemoglobin for the three groups. The mean methaemoglobin for the sulphasalazinetreated group was significantly higher than that of the controls $(P<0.001)$. Twenty-one of the patients receiving sulphasalazine had a level of methaemo- globin greater than $1 \cdot 70 \%$ (mean $+2 \mathrm{SD}$ of control group). This rise in methaemoglobin was not related to the dose of sulphasalazine, the serum total sulphapyridine level, or any other haematological abnormality. All except one of the untreated colitics had a methaemoglobin level in the normal range; the one exception had a level of $1.80 \%$ but was taking nitrofurantoin.

Heinz bodies were found in the red cells of one patient taking sulphasalazine. Howell-Jolly bodies were not observed.

\section{Discussion}

Thirty-five of the 50 patients treated with sulphasalazine were found to have one or more red cell 


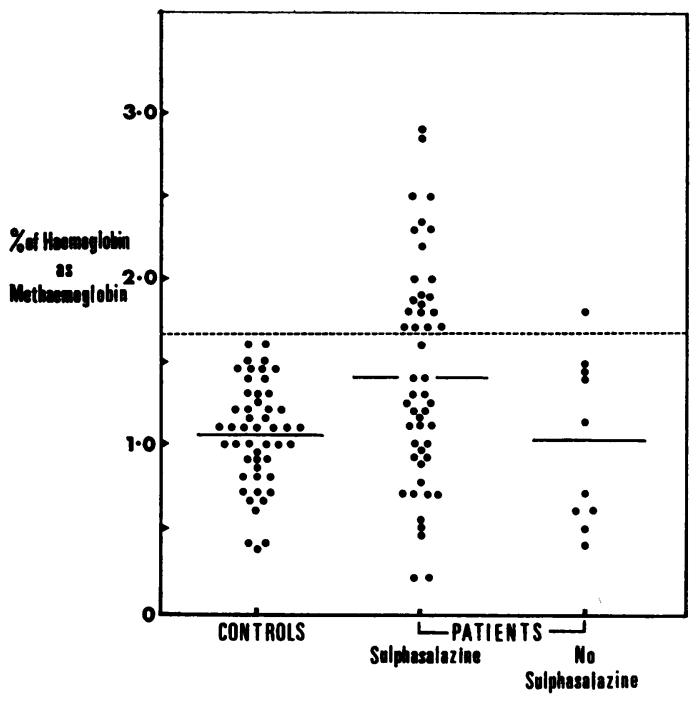

Fig 3 Percentage of haemoglobin as methaemoglobin. Horizontal bars show mean of each group; broken line 2SD above mean of control group.

abnormalities, which can be attributed to the drug therapy. This incidence is much higher than that described in earlier reports (Böttiger et al, 1963; Dick et al, 1964; Das et al, 1973a).

The presence of contracted red cells was associated with a significant rise in the reticulocyte count $(P<0.05)$ and MCV $(P<0.05)$. Apart from a low serum folate level in one patient, the rise in MCV can only be explained by a younger red cell population and the small rise in reticulocyte count. The results suggest that the observed red cell contraction is associated with mild haemolysis, not sufficient in these patients to cause anaemia or a rise in the serum bilirubin concentration.

The total sulphapyridine level in the serum depends on the intake of sulphasalazine and rate of excretion of sulphapyridine and its metabolites. Sulphapyridine is polymorphically acetylated in man and slow acetylators tend to have a higher serum total sulphapyridine level (Schröder and Evans, 1972; Das et al, 1973b). In the present study, the patients with contracted red cells had a significantly higher mean serum total sulphapyridine level than those with undamaged red cells $(P<0.001)$, and had a lower percentage of acetylated sulphapyridine in the serum $(P<0.02)$. Figure 4 shows the percentage of patients with contracted red cells for five different doses of sulphasalazine, two patients being excluded as they had taken the unusual doses of $0.5 \mathrm{~g}$ and 3.5 $\mathrm{g}$ /day. Slow and fast acetylator status was deduced from the percentage of sulphasalazine in the acety-

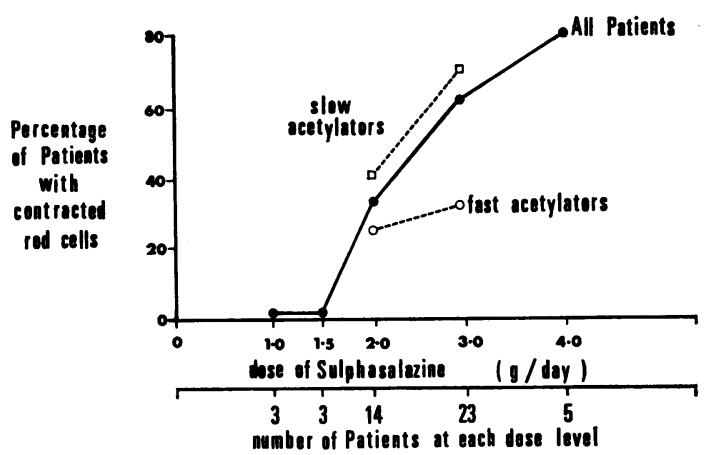

Fig 4 Incidence of red cell contraction related to dose of sulphasalazine and acetylator status (48 patients receiving sulphasalazine).

lated form. Patients with $0-50 \%$ acetylated sulphapyridine were classed as slow acetylators and those with $51-100 \%$ as fast acetylators. This indirect method of determining acetylator status was used, as Schröder and Evans (1972) and Das et al (1973b) have shown that slow acetylators have a low percentage of sulphapyridine in the acetylated form (means of 24.5 and $38.5 \%$, respectively) and fast acetylators have a higher percentage (means of $62 \cdot 3$ and $72 \cdot 8 \%$ ). The numbers of patients are small at the low and high dose levels but fig 4 indicates that red cell damage is related to the dose of sulphasalazine and acetylator status.

Hyposplenism has been associated with the occasional case of ulcerative colitis (Ryan, Smart, Preston, and Holdsworth, 1974; Goodyear and Forster, 1974). Although it could result in damaged or contracted red cells persisting, in this series we did not observe any Howell-Jolly bodies to suggest hyposplenism.

None of the patients investigated had severe haemolysis, although we have observed this in other patients receiving sulphasalazine. Das et al (1973a) described five such patients in whom the haemolysis was related to a large dose of sulphasalazine and a high total serum sulphapyridine level. It seems likely that the difference between the mild and severe forms of haemolysis is quantitative rather than qualitative (Dacie, 1967). The patients whom we studied were taking small maintenance doses of sulphasalazine and developed mild haemolysis only.

Two patients were found to be folate deficient. A third patient had developed folate deficiency while receiving sulphasalazine and was taking folic acid supplements at the time of the study. Although the drug may interfere with folate absorption (Franklin and Rosenberg, 1972), it is also possible that the 
folate depletion is in part due to chronic druginduced haemolysis. Sulphonamide-induced haemolysis may be severe in G6PD-deficient patients, but this study confirms that sulphasalazine-induced red cell damage can occur in the presence of normal levels of G6PD (Gabor, 1973). Autoimmune haemolysis, detected by a positive direct or indirect antihuman globulin test, has been reported in occasional patients receiving sulphasalazine (Shinton and Wilson, 1960; Fishman et al, 1973). We found no evidence of such sensitization, but did not perform any antihuman globulin tests in the presence of added sulphasalazine.

The presence of elevated levels of methaemoglobin appears to be due to the sulphasalazine therapy, rather than to the colitis itself. The untreated colitic who had an elevated level of methaemoglobin was taking nitrofurantoin, which is an oxidant drug and could be expected to cause this abnormality. Such an association has not been described, but nitro compounds are reported to cause the abnormality (Prankerd, 1961). Sulphasalazine-induced methaemoglobin is not dose-related, hence if a patient develops 'cyanosis' the drug should be withdrawn.

Sulphasalazine is undoubtedly a useful and generally safe drug. The major advantage of maintaining a remission of colitis must be compared with the possibility of chronic mild haemolysis and methaemoglobinaemia. The two trials (Misiewicz et al, 1965; Dissanayake and Truelove, 1973) that demonstrated the effectiveness of sulphasalazine for the maintenance therapy of ulcerative colitis both used a dose of $2 \mathrm{~g} /$ day. Even at that low dose, we have demonstrated that $33 \%$ of the patients had contracted red cells and $34 \%$ had elevated levels of methaemoglobin.

This study suggests that $1.5 \mathrm{~g} /$ day of sulphasalazine is not likely to cause red cell damage, and if this dose protects against exacerbations of colitis it may be a safer dose for the long-term treatment of the asymptomatic colitic. Patients receiving sulphasalazine, especially at the start of treatment, or following an increase in the dose, should have regular observations of the blood film, MCV, and haemoglobin. If haemolysis is detected, a reduction in the dose of sulphasalazine may correct the abnormality.

Dr J. Parker Williams (consultant haematologist, Central Middlesex Hospital) inspired this investigation, and we are grateful for his help and advice at all stages. We would also like to thank $\operatorname{Dr} \mathrm{S}$. M. Worlledge (Hammersmith Hospital) who performed the direct antihuman globulin tests.
References

Best, W. R. (1963). Drug-associated blood dyscrasias. J. Amer. med• Ass., 185, 286-290.

Böttiger, L. E., Engstedt, L., Lagercrantz, R., and Nyberg, A. (1963). The occurrence of Heinz bodies during Azulfidine treatment of ulcerative colitis. Gastroenterologia (Basel), 100, 33-41.

Cohen, S. M., Rosenthal, D. S., and Karp, P. J. (1968). Ulcerative colitis and erythrocyte G6PD deficiency: salicylazosulfapyridine-provoked hemolysis. J. Amer. med. Ass., 205, 528-530.

Dacie, J. V. (1967). The Haemolytic Anaemias, Congenital and Acquired. Part IV, 2nd ed., pp. 1035-1036. Churchill, London.

Dacie, J. V., and Lewis, S. M. (1968). Practical Haematology, 4th ed., pp. 493-496. Churchill, London.

Das, K. M., Eastwood, M. A., McManus, J. P. A., and Sircus, W. (1973a). Adverse reactions during salicylazosulfapyridine therapy and the relation with drug metabolism and acetylator phenotype. New Engl. J. Med., 289, 491-495.

Das, K. M., Eastwood, M. A., McManus, J. P. A., and Sircus, W. (1973b). The metabolism of salicylazosulphapyridine in ulcerative colitis. 1. The relationship between metabolites and the response to treatment in inpatients. Gut, 14, 631-641.

Dick, A. P., Grayson, M. J., Carpenter, R. G., and Petrie, A. (1964). Controlled trial of sulphasalazine in the treatment of ulcerative colitis. Gut, 5, 437-442.

Dissanayake, A. S., and Truelove, S. C. (1973). A controlled therapeutic trial of long-term maintenance treatment of ulcerative colitis with sulphasalazine (Salazopyrin). Gut, 14, 923-926.

Dyer, N. H. (1972). Medical management of Crohn's disease. Clin. Gastroent., 1, 449-467.

Evelyn, K. A., and Malloy, H. T. (1938). Microdetermination of oxyhaemoglobin, methemoglobin and sulfhemoglobin in a single sample of blood. J. biol. Chem., 126, 655-662.

Fishman, F. L., Baron, J. M., and Orlina, A. (1973). Non-oxidative hemolysis due to salicylazosulfapyridine: evidence for an immune mechanism. Gastroenterology, 64, 727.

Franklin, J. L., and Rosenberg, I. H. (1972). Impaired folic acid absorption in inflammatory bowel disease: effects of salicylazosulfapyridine (azulfidine). Gastroenterology, 62, 845.

Gabor, E. P. (1973). Hemolytic anemia as adverse reaction to salicylazosulfapyridine (Letter). New Engl. J. Med., 289, 1372.

Gardner, M. D., and Bargen, J. A. (1964). Hemolytic anemia secondary to salicylazosulfapyridine therapy. J. Amer. med. Ass., 190, 71-72.

Goodyear, M. D. E., and Forster, D. C. (1974). Hyposplenism in ulcerative colitis. Lancet, 2, 658.

Harvey, A. M., and Janeway, C. A. (1937). The development of acute hemolytic anemia during the administration of sulfanilamide. J. Amer. med. Ass., 109, 12-16.

Hansson, K. A., and Sandberg, M. (1973). Determination of sulphapyridine and its metabolites in biological materials after administration of salicylazosulphapyridine. Acta pharm. Suec., $10,87-92$.

Misiewicz, J. J., Lennard-Jones, J. E., Connell, A. M., Baron, J. H., and Jones, F. A. (1965). Controlled trial of sulphasalazine in maintenance therapy for ulcerative colitis. Lancet, 1, 185-188.

Moeschlin, S. (1940). Innenkörper-Anämien durch Entsteheng vor Methämoglobin infolge Dagenan-Wörkung (Sulfapyridin). Schweiz. med. Wschr., 70, 786-790.

Prankerd, T. A. J. (1961). The Red Cell, p. 140. Blackwell, Oxford.

Ryan, F. P., Smart, R. C., Preston, F. E., and Holdsworth, C. D. (1974). Hyposplenism in ulcerative colitis. Lancet, 2, 318-320.

Schrõder, H., and Campbell, D. E. S. (1972). Absorption, metabolism and excretion of salicylazosulphapyridine in man. Clin. Pharmacol. Ther., 13, 539-551.

Schröder, H., and Evans, D. A. P. (1972). Acetylator phenotype and adverse effects of sulphasalazine in healthy subjects. Gut, 13, 278-284.

Shinton, N. K., and Wilson, C. (1960). Autoimmune haemolytic anaemia due to phenacetin and p-aminosalicyclic acid. Lancet, $1,226$.

Spriggs, A. I., Smith, R. S., Griffith, H., and Truelove, S. C. (1958). Heinz-body anaemia due to salicylazosulphapyridine. Lancet, 1, 1039-1042.

Svartz, N. (1942). Salazopyrin, a new sulfanilamide preparation. Acta med. scand., 110, 577-598. 